\title{
IV）脾網内系の微細構造, 特に赤色骾の電子顕微鏡的観察
}

\author{
神戸大学医学部病理学第一講座*
}

家森武夫森芳茂

緒言

我々は, 各種菛器に於ける結核性細胞反応の電子顕 微鏡観祭を行った一連の垁験に於て, 脾臟に於ける結 核結節(5)6)7)の研究を試み, 1956年先ず, 超薄切片の位 相差顕微鏡観祭を行って以来, 主として家鬼の全身網 内系細胞の観察結果を報告13)14)15)して来た。脾に於け る網内系細胞の微細構造についても, すでに本学会第 3 回総会に於けるシムポジウムに於ても触れておい た.しかし乍ら我々の従来の報告は, 主として, 個々 の細胞の形態のみにその重点がおかれ細胞相互の関係 については把握のそしかった点をまぬがれない。

諸外国に於ては, 脾臟の電子顕微鏡的研究は, 現在 亿於ても比較的少く, Weiss,9)10)11)12) Galindo 等 2)3), Roberts等8)のものが数えられるにすぎない.

本邦に於ては, 我々以外では, 小山等4)の報告が見 られるのみである.今回は, 従来の観察を補うため, 主として無処置家鬼を用いて, 出来る限り広範囲の連 続写真莸貼り合わせることによって, 細胞相互の関係 を明らかにしながら, 各網内系細胞の形態を再検討し た.

\section{観察材料ならびに方法}

動物は, 体重 $2 \mathrm{~kg}$ 前後の白色家鬼在用いた。家鬼は 三群に分け, 無処固家旡, 屠殺 2 時間前に10倍稀釈ペ リカンィンキ $5 \mathrm{cc}$ を目静脉内に注射したもの及び脾動 脉内又は脾内に直接10倍稀釈チフスワクチン（腸チフ ス, パラチフス混合死菌ワクチン) を接種し, 以後経 時的に屠殺したもののうち，3日目迄のものを用い た。

屠殺は, 頸動脉切断により失血死せしめ, 直ちに, 燐酸緩衝 $1 \%$ オスミウム酸に 1.5 時間固定した. 以後 法の如く上昇アルコール列により脱水, エポン 812 に 包理した. 一部は, 脱水中に, 燐タングステン酸染色
を行った，薄切は, Leitz 社製造ミクロトームスは L.K.B. 社製 Ultratome によった. 観察は, 日立HU -11 型により, 比較的低倍率（直接倍率 2,000 又は 3,000 倍）で, 広範囲の切片を連続撮影し, 拡大の後貼り合 わせて, 倜々の細胞の相互関係を明らかにするように 心掛けた。

\section{観 察 結 果}

赤色脾髄の広範用な貼り合せパノラマ写真の観察に よって, 構成細胞を分類すると, 静脉洞内皮細胞, 固 定性細網細胞, 食食性細網細胞, 細動脉周囲細網細胞 （莢動脉周囲細胞）, リンパ球系細胞, 形質細胞, 静 脉内皮細胞より成っている.乙れらの細胞の出現頻度 は,リンパ球系細胞50個に対し, 固定性細網細胞 10 個, 食食性細網細胞 10 個, 形質細胞 5 個の割合である.

以下網内系細胞の個々のものについて, その微細形 態を述べる。

1）静脉洞

a）基底膜

静脉洞壁は，内皮細胞と基底膜とよりなる．基底膜 は, 内皮細胞の外側に兒られるが, 連続的に, 全静脉 洞を包囲するものではなく，随所に不規則な断裂を示 している. 又基咸膜の構造の, 他の任管系の基底膜の 如き規則的な三層構造を坔さず, 所によって中等度の 電子濃度を有する無構造物質の集塊のように見える部 分が多く, 厚さも区々である。高倍率写真でみると, この基底膜は, 極めて微細な細線維状物質よりなって いるが, 翏原線維のような規則的な周期性を示す線維 はこの中には見られない. との断裂した基底膜の像 は, 光学顕微鏡所見から, 桶のたが状に静脉洞を取り 巻く好銀線維の断面と考えられるが, 全く同一のもの かどうかは現在の所では確言しにくい.

基底膜は, 静脉洞より, 静脉に近づくにつれて, 次 第に連続性となり, 三層の構造も, 次第に規則性を示 
し，固有血管壁の構造に移行する.

ての基底償の断裂部は, しばしば，赤血球やリンパ 球の通過する道となっている.

b）洞内皮細胞

洞内皮細胞は, 基底膜の内側を被覆するのが, 基底 膜と同様にその被覆にも断裂を熟める部分がある. 細胞質は摒平で, 核の存在部位のみが, 内腔に突出し ている，核の電子濃度は中等度で，細網細胞のそれに 比しや〉高い，核質はびまん性であるが，時に核周 及び核中央部に集合する傾向を示すものもある，細 胞質には, 円形又は, 短桿状の糸粒体が分布し, 多数 の小空胞状滑面小胞体がびまん性に見られる，短い粗 面小胞体も散在性にみられる。遊離りボゾームは, 少 数であるが，集塊を形成する部分もある．核側にはゴ ルジ装圆が見られるが小型である.隣接する内皮細胞 の閐には, tight junctionは見られない場合が多 く, 僅かな空陌を残して相隣る細胞膜が存在し, との 空隚は, しばしば, 赤血球, 細網細胞突起の通過する 道となっている。

チフスワクチン接種動物では, 無処置例に比し, 洞 内皮細胞の丈が一般に高く, 糸粒体を始め, 細胞質小 器官の発達が良好で, 時に赤血球を貪食する像や, 高 電子濃度性の lysosome 顆粒を見るととがある.

2) 細網細胞

随索内細網細胞は, 固定性細網細胞と貪食性細網細 胞の二種よりなり, 固定性細網細胞は, 更に静脉洞壁 在性のものと, 能道内に散在するものとの二種に分け られる。

\section{a）固定性細網細胞}

静脉洞壁に接して存在する細網細胞は，洞基底膜を 裹打ちするかの如くに，細長い細胞質を伸展してい る. この洞壁に伸展している細胞質は, 内皮細胞のそ れよりもむしろ薄い場合が多い。との細網細胞は, 韨 索の中心部に向っても, 不規則な突起を出し, 他の細 胞の間に，細胞質突起が断片的に見られる. 細胞の大 きさは，核周の部分で約 $10 \mu$ 程度のものが多い，核 は，楕円形又はわずかな陥凹を示し，核質は概ねびま ん性である，核小体は，小型のものが $1 ， 2$ 個見られ るととが多い。細胞質内には, 小型（最大長径 $0.7 \mu$ 内 外, 短径 $0.2 \mu$ 内外) の桿状糸粒体が, 散在性にみら れ，系粒体には，通常の cristae が見られるが，系 粒体基質は中等度の電子濃度を示す。細胞質内には, その他, 少数の粗面小胞体, 小空胞状滑面小胞体が散 在しているが, 粗面小胞体は, 時に内腔が拡大して, 低電子荟度性物質を入れることがあるが，囷板状配列 を示すととは少い，遊離りボゾームは少数認められる
にすぎない.時に小型の lysosome 性顆粒が存在し ている，基底膜断裂部を通して，細胞質突起の一部 が, 内皮細胞下又は, 静脉洞内に露出しているととも ある.

髄索内部に散在する細網細胞は, 静脉洞壁在性のも のと，あたかも網工を形成するかのように，不規則な 細長い突起を多数に形成し，他種細胞間にその細胞質 を伸展している。細胞突起の間には, 静脉洞基底膜と 同様な電子濃度を示す無形性物質が見られ，乙の細胞 が互いに連絡した基底膜様物質（光顕的好銀線維に相 当すると考えられる）と共に，細網組織を形成してい ると考光られる.

細胞質の大きさや，核の性状，細胞質内小器官の 形, 性状, その分布は, 洞壁在性のものと極めて類似 した形態を示し, 同種細胞が, その存在位置に従って若 干の形態的差異を示すにすぎないと考元られる。との 細網細胞の突起も, 洔に壁在性細網細胞の間を通って, 静脉洞内皮下, 又は, 洞内に直接露山するととがある.

b）貪食性細網細胞（Macrophage）

細胞体は大型で, 15〜20 $\mu$ 亿及び, 時には更に大型 のものが見られる，髄索内に散在性に見られるが，静 脉洞に近い部分により多く存在している.

核は，不規則な楕円形又は宿凹を示すものが多く， やや偏在し，核質はびまん性であるが，わずかなが ら, 核膜に沿って集塊を作る傾向を有し，小型又はや や大型の核小体を $1 \sim 2$ 個有している.

細胞質は, 固定性細網細胞に比し, 突起が少なく, 種々の細胞質内小器官がよく発達している，糸粒体 は, 主として細胞質の広い侧に存在し, 円形ないし長 桿状で, $0.7 \mu \sim 0.3 \mu$ で大小不同である. 系粒体膜, cristae には特に所見はないが，基質はやや電子密度 が細胞質より高く，微細顆粒状を示す。粗面小胞体 は, 短い, 狭い裂状を示すものが多く,やや群在し， 層板状配列に近い所見を示す.内腔がやや昖大し, 中 等度の電子濃度を持つ物質を含むものがある、小空胞 状滑面小胞体が，びまん性に散在している.ゴルデ装 置はよく発達し, 膜, 小空胞より成るものが, $2 \sim 3$ 群集合して見られる.

特徴的な所見は，一屏の限界膜に包まれた頜食体 (phagosome) 又は消化小体 (digestion body 家森), lysosome の存在である.内腔は,びまん性, 顆粒状, 集塊状等種々であるが，一部にはこエリン像を示すも のも見られる、時には，赤血球等の大型貪食物を見る ととがある。

貪食性細網細胞と固定性細網細胞との間には, 微細 構造の上で類似点が多く, 同一起源の細胞の特に圓食 
機能の元進したものと考えられる. この雨者の間に は, 移行形と考元られる細胞も存在している.

3）荻動脉周囲細胞

家态は，従来荻来動脉を持たない動物とされている が, 電顕的には， $2 \sim 3$ 周の細胞及び不規則な基底膜 様物質で取り用まれたものが存在する。

このような動脉周囲細胞は, 紡錘形で求心性に配列 している. 胞体は比較的小さく, 長径 $10 \mu$ 前後のもの が多い，核はやや偏在し，核質は，核膜に沿って集塊 を作る傾向を示し，小型の核小体を 1 個持つものが多 い. 細胞質には, 円形又は短桿状の系粒体, 粗面小胞 体が中等度に見られ，時に粗面小胞体の内腔がやや拡 大して, 中等度の電子濃度を有する物質を入れている ととがある、ゴルジ装置は，膜及び小空胞よりなり， リボゾームが散在性に見られる。時にリボゾームは集 塊を作るとともある。高電子濃度の lysosome 顆粒 や，少数の貪食体を有するものが見られる。乙のよう な性格は, いずれも細網細胞のそれに極めて類似し， ての細胞の細網細胞性を示している.

以上各個の網内系細胞の微細構造について述べた が, チフスワクチン接種時の結果は, 極めて早期のも ののみであるので, 以後のものについては, 更に検討 の後, 報告する.

$$
\text { 考案 }
$$

脾臓に於ける網内系細胞を, パノラマ的貼り合わせ 写真によって, 相互関係を観察しながら, その微細構 造を検討した結果, 静脉洞内皮細胞, 固定性細網細胞, 貪食性細網細胞, 萊動脉周囲細網細胞䎲分類し, 固定 性細網細胞を, 更に静脉洞壁在性細網細胞と随索内細 網細胞に分けてその構造を述べた。すでに触れた如 く, 我々は, 昭和 31 年以来, 先ず超薄切切片の位相差 顕微鏡観察，そのギムザー染色所見の観察に続いて， 電子顕微鏡観察の結果を発表して来たが，てれらの所 見は, 電子顕微鏡観察に際しては特に, 個々の細胞の 内部構造を主眼とし，その相互関係を確認するような 観察所見に欠けるとてろがあった. 各細胞の微細構造 は, 根本的には, 第三回網内系学会シムポジウムで総 論的に論じた網内系細胞の所見と差が認められなかっ たが，その相互関係を今回明らかにし得た。

静脉洞内皮細胞については，すでに赤崎一門1) の研 究により, この細胞が相当早期の発生段階に於て, 細 網細胞とは別個の分化をとげるととが明らかにされて いる. 電顕的観察によっても, 無処置動物に於ては, 固有血管内皮に類似した形態を示すものであるが，チ
フスワクチン等の刺载下では，その微細構造が，細網 細胞に近い形態を示すととがある. 我々がかつて報告 した結核性炎症に際しても，同様な傾向を示した。

剈遖索内細網細胞も，固定性と領食性とは無処置動物 に於ては, 貪食物や, lysosome の出現の点が異る が，その固有の構造は，互いに類似した点が多く，被 刺戟下に於ては, 固定性細網細胞の遊離により貪食性 細網細胞への移行が行われうるものと考光られる， さて諸外国に於ける脾の系統的な電子顕微鏡観察の報 告は Weiss ${ }^{9)}$ によるのが最も早く，後に Galindo 等2)3) Roberts 等8) のものが挙げられる.

Weiss は1957年以来，超薄切片のPAS ヘマトキ シリン染色の光学顕微鏡所見と, 電子顕微鏡所見とを 比較検討した結果を報告している，彼によると，静脉 洞と咀索とは，等しく血流路であり，両者の差は，単 に内腔が拡大しているか, 虚脱状であるかの差にす ぎないする，従って，基底膜を被覆する細胞も，全 く同一種の細胞であり，環境の差によって多少の形態 的差異を示すにすぎないとしていた．しかし後12)に彼 は, sinal lining cell と cordal lining cell の形態 的, 機能的差異を認めている.

Galindo 等2)3) も, 脾臟の白色髄及び赤色髄の微細 構造を報告し, 固定形細網細胞を $\mathrm{A}$ 型及び $\mathrm{B}$ 型の二型 に分類している，彼によれば，A型は電子濃度の高い 細胞で，細網線維に特に密接な関係を有し，PTA （リンタングステン酸）染色によりよく染まるととを 述べている.

Roberts 等8) は, 細網細胞を I , II 及び III型に分 類し，I型は最も未分化で，核質の電子濃度が低く， リボゾームの遊離型が少く， II， III 型の母細胞と考光 ている． III型は，分化の最も進んだもので，Galindo のA型に相当している. しかし Roberts によると， 静脉洞及び艏索の基底膜を被覆する細胞には特定なも のがなく，上記三型のいずれもその性格を有し， Weiss $の$ cordal lining cell (cordal epithelium) $の$ 形態に疑義を唱えている. 本邦に於ては, 小山等は, 明瞭江静脉洞内皮細胞之㵦索細網細胞を別個に記載 し，我々の所見と略同一の意見を報告している.

以上の諸外国の報告は，いずれも，広範な写真の観 察によって相互関係を充分考虑しない時に陷る誤をお 功ている. 特に脾藏の如き複雑な構造の部分的強拡 大写真の観察では, 各個細胞の鑑別に困難を感ずるて とが多い，我々の今回の観察結果では，静脉洞内皮は 形態的に噵索細網細胞と全く異った配置と性格を示す が, やや肥大した細胞質の一部のみを比較する際に 
は，大きな差異を見出し難い時のあるととを知った。 特に軽度の刺戟状態に置いた際の洞内皮の活性化を認 める時にその状態が顕著である.

喵索細網細胞については, 一応二型に分類出来る が，固定性細網細胞の二型の差は，位置的な差による と考えられる.いずれの細胞も, 時に静脉洞内に突起 在出可所見からも，それが示されている，貪食性細網 細胞は, 乙の固定型細網細胞の貪食能が顕著に現われ た形態と考えられ，当然しの固定型より貪食型への移 行が行われると推定しうる。このととは，今後更に考 究したい.

脾藏特に赤脾髄の末端の間題は, 種々論議されてい $\tau$, 電顕所見でも, Weiss, 小山等の如く, 動脉末端 が赤脾跹内に，開放性に終る所見を報告しているが， 今回の報告では，我々はそれに関する批判の材料に接 するととが出来なかった．唯, 従来家鬼は荻動脉の存 在しない動物の中に数えられているが, 電子顕微鏡的 所見から，類似の構造が存在するととを見出した。 又 その周囲細胞は, 紐網細胞に一致する形態を示すとと を述べた。

$$
\text { 結論 }
$$

脾㵴赤色蹃の構造をパノラマ的貼り合わせ写真を用 いて電子顕微鏡観察を行い次の如く網内系細胞を分類 した.

1. 静脉洞内皮細胞

2. 䟧索細網細胞

a. 国定性細網細胞

i）静脉洞壁在性固定性細網細胞

ii) 髄索内細網細胞

b. 貪食性細網細胞

3. 莢動脉周囲細網細胞

これらの個々の細胞の微細構造を記載した.

$$
\text { 謝辞 }
$$

第 3 回網内系学会シムポジウムに引き続き, 本シム ポジウム参加の機会を与えられた, 日比野総会会長, 赤崎名誉教授, 飯島教授を始め, プログラム委員の諸 教授に厚く感謝致します. 又本稿の完成に協力された 教室員各位に深謝します。

$$
\text { 文献 }
$$

1）赤崎兼義：細網内皮系統とその腫愓. 日病 会誌， $41,1-26$, 昭和 27 年.

2) Galindo, B. \& Imaeda, T. : Electron microscopic study of the white pulp of the mouse. Anat. Rec., 143, 399-415, 1962.

3) Galindo, B. \& Freeman, J.A. : Fine structure of splenic pulp. Anat. Red., 147, 25-41, 1963.

4) Koyama, S., Aoki, S. \& Deguchi, k. : Electron microscopic observations of the splenic red pulp with special reference to the pitting function. Mie Med. J., 14, 143-188, 1964.

5）森芳茂, 福水瞭, 家森武夫：脾臟結核結節 形成に関する電子顕微鏡的観察. 日病会誌, 49,779 , 炤和 35 年.

6）森芳茂, 福水 膫, 家森武夫：脾臓細網細胞 の電子顕微鏡的観察. 日病会誌，50,232, 明 和 36 年, 51,529 , 昭和 37 年

7）森芳茂, 福水 膫. 家森武夫：脾細網細胞の 電子顕微鏡的観察. 日網会誌, 1,77 , 昭和 36 年, 2,83 , 昭和 37 年.

8) Roberts, D.K., \& Lotta, J.S. : Electron microscopic studies on the red pulp of the rabbit spleen. Anat. Rec., 148, 81-101, 1964.

9) Weiss, L. : A study of the structure of splenic sinuses in man and in the albino rat with the light microscope and the electron microscope. J. Biophys. \& Biochem. Cytol., 3, 599-610, 1957.

10) Weiss, L. : An experimental study of the organization of the reticuloendothelial system in the red pulp of the spleen. J. Anat., 93, 465-477, 1959.

11) 同: The structure of fine splenic arterial vessels relation to hemoconcentration and red cell destruction. Amer. J. Anat., 111, 131-174, 1962.

12) Weiss, L. : Structure of intermediate vascular pathways in the spleen of the rabbits. Amer. J. Anat., 113, 5191, 1963.

13）家森武夫, 佐々木正道, 森芳茂, 松浦覚, 網内系細胞の電子顕微鏡像. 最新医学, 17 , $1022-1032$, 昭和 37 年.

14）家森武夫, 森芳茂：網内系の細胞学(シンポ ジウム). 2. 電子顕微鏡の立場から. 
a） 網内系の細胞学, 日網会誌, 3, 64-75, 昭和38年.

15) Yamori, T. and Mori, Y. : Electron microscopic observation of the reticuloendothelial system. Tohoku J. exp. Med., 81, 330-339, 1964. 


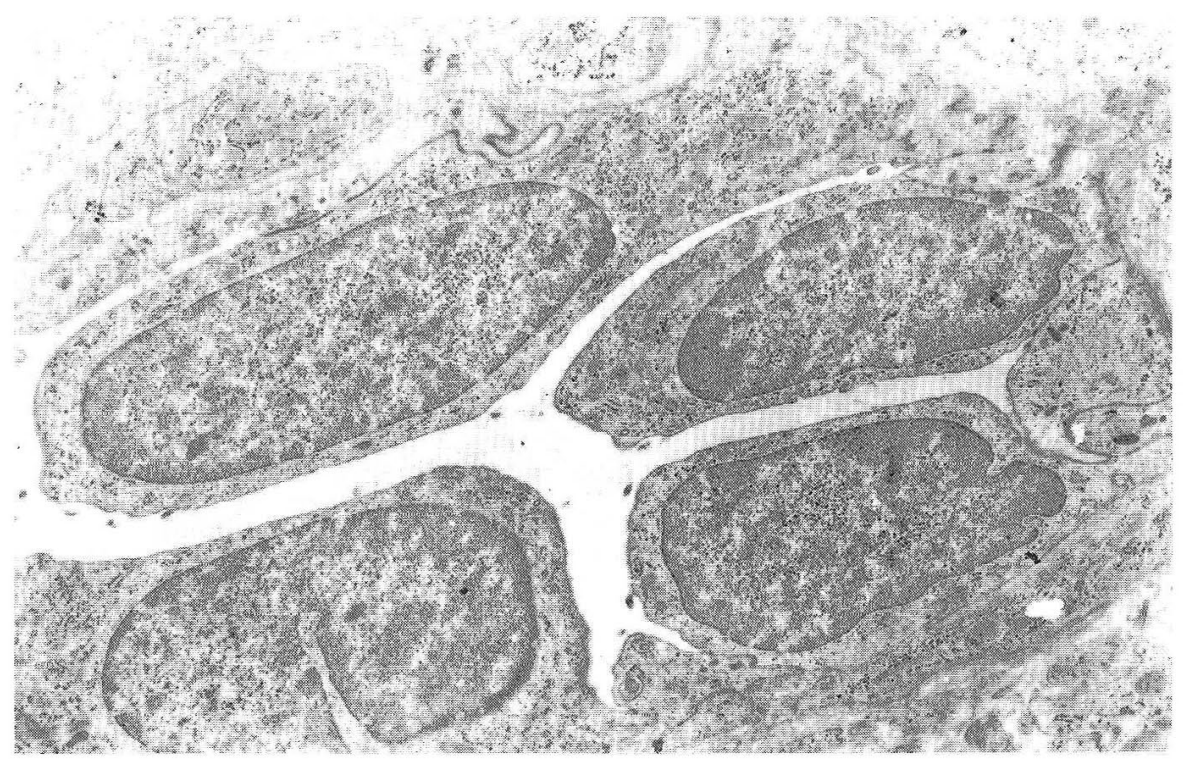

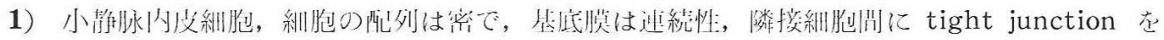

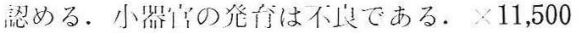

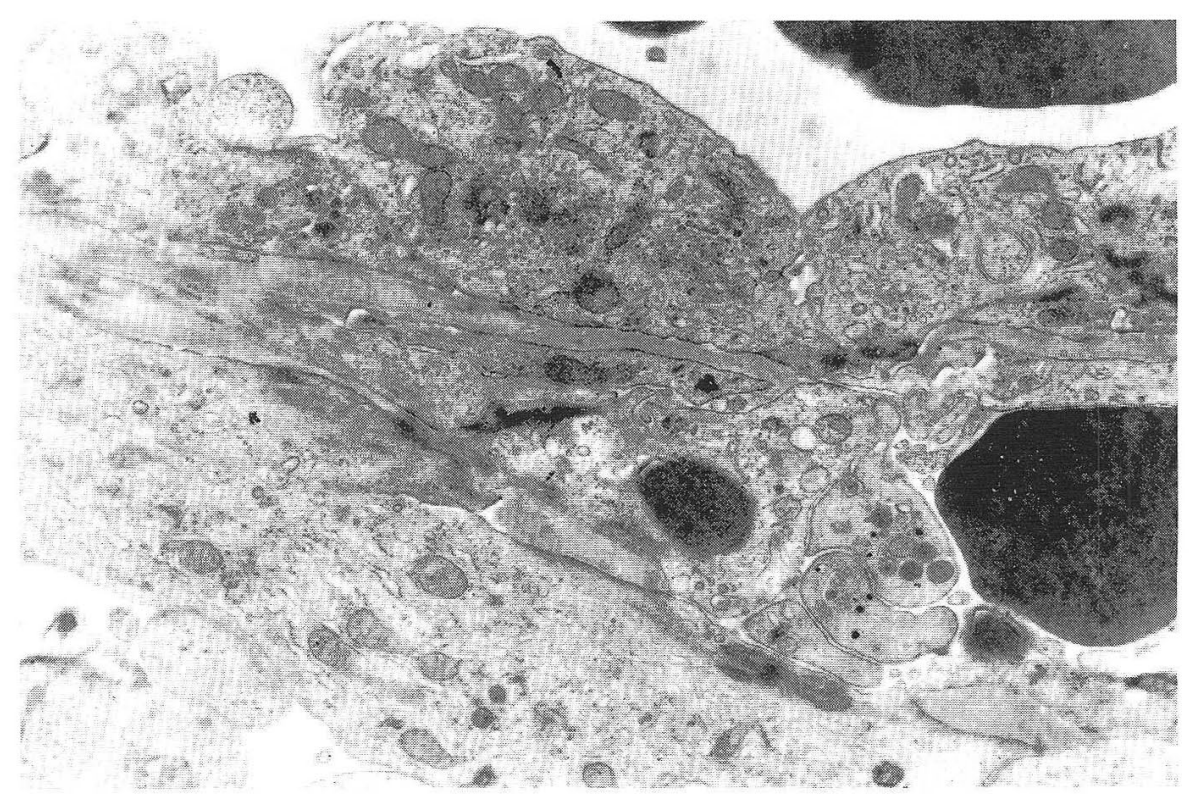

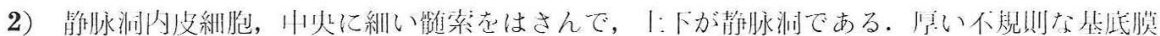

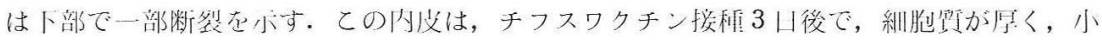

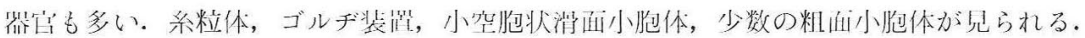
下方の内皮縕胞内に細線維構造が允られる。 × 11,500 


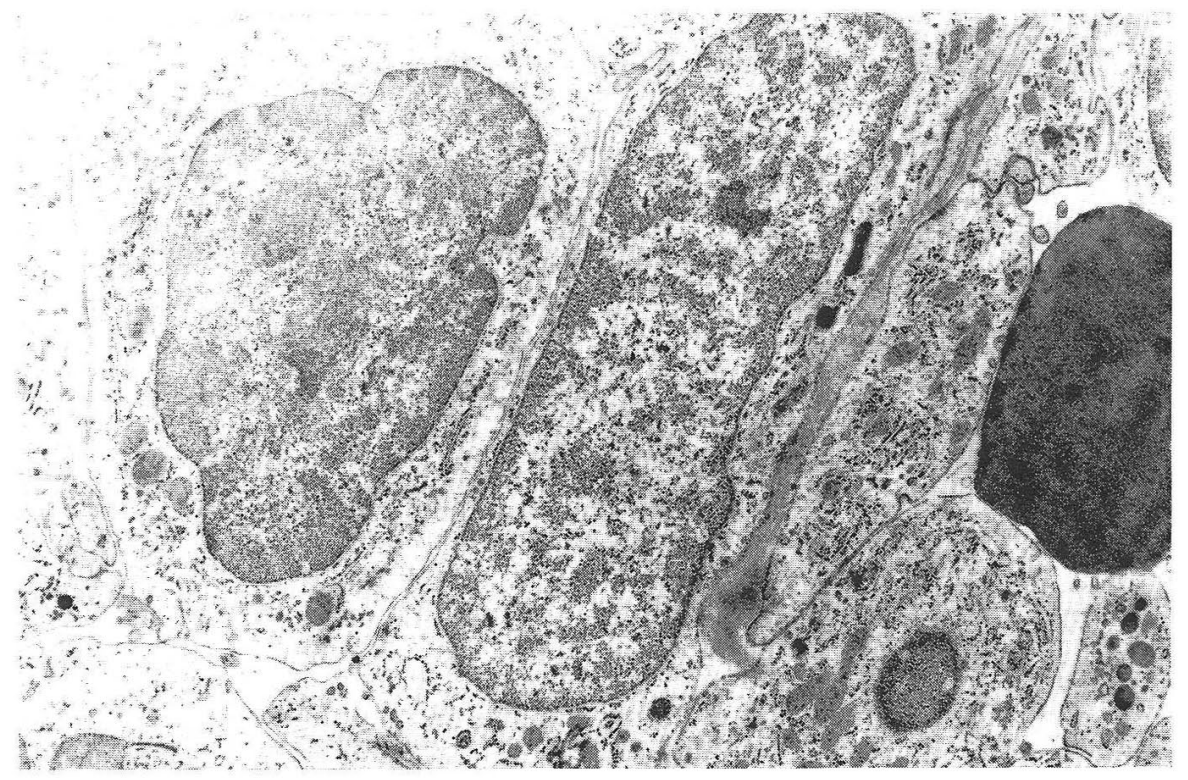

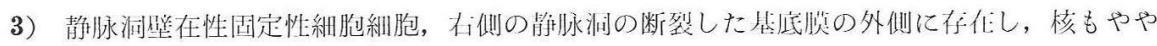

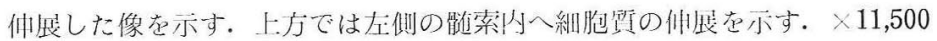

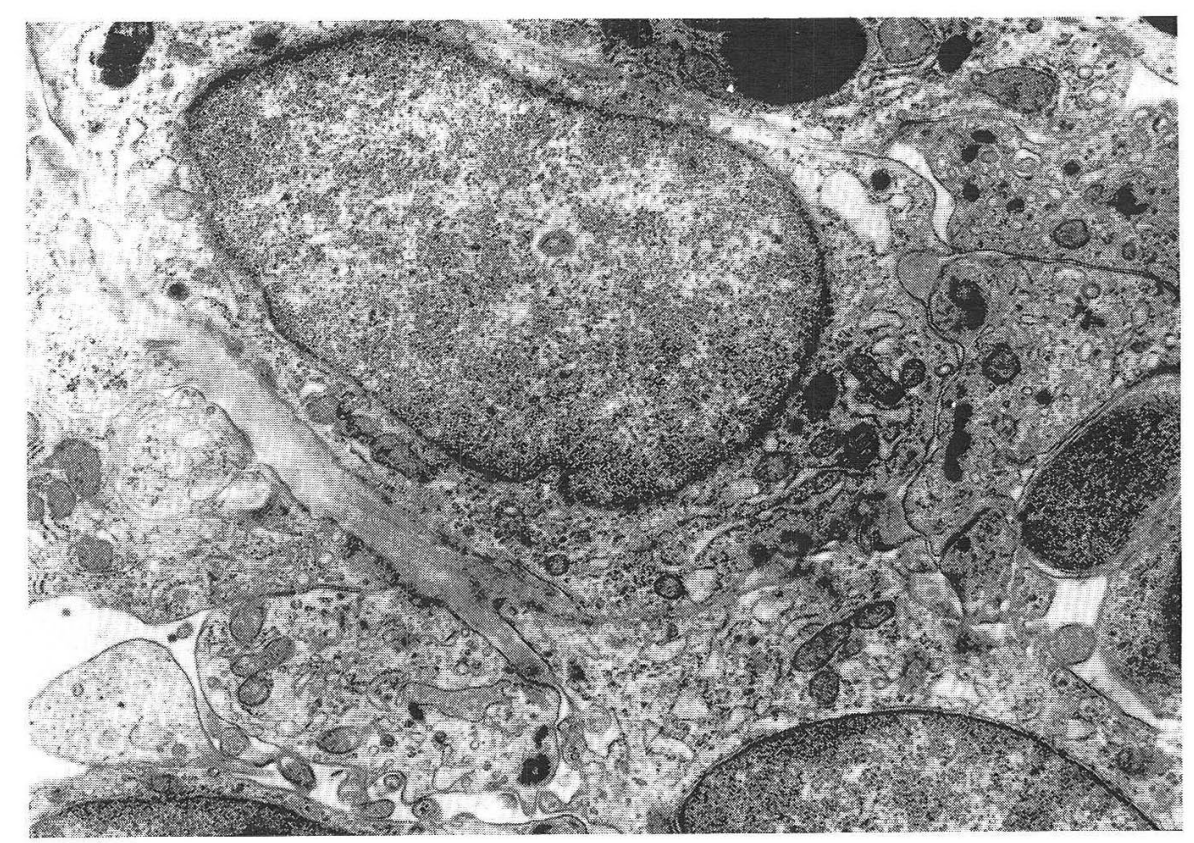

4) 3)と同様な細胞であるが, lysosome が大さく, 粗面小胞体の队腔拡大, リボゾームの增 㞦が見られる。活性度の高い細胞と考えられる。基底漠は細線維状である。 $\times 11,500$ 


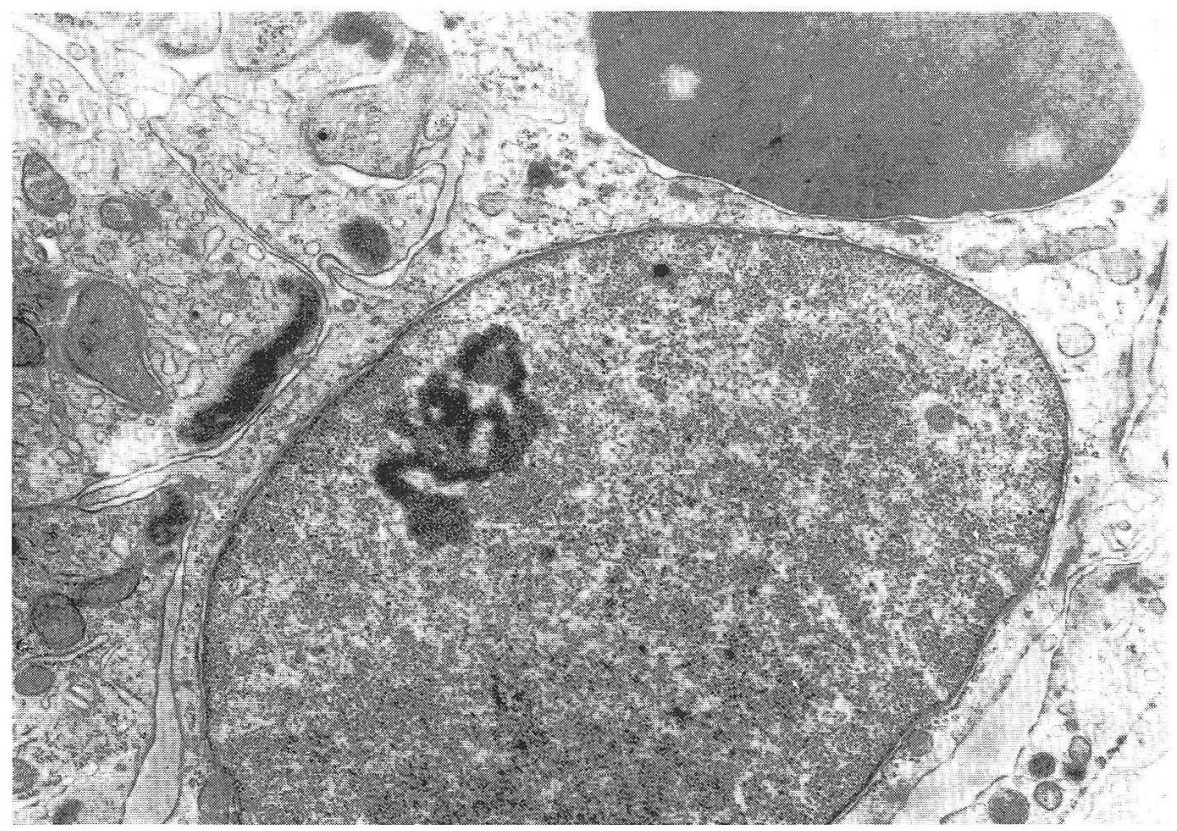

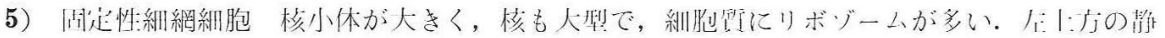

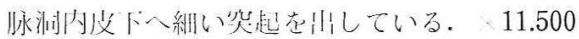

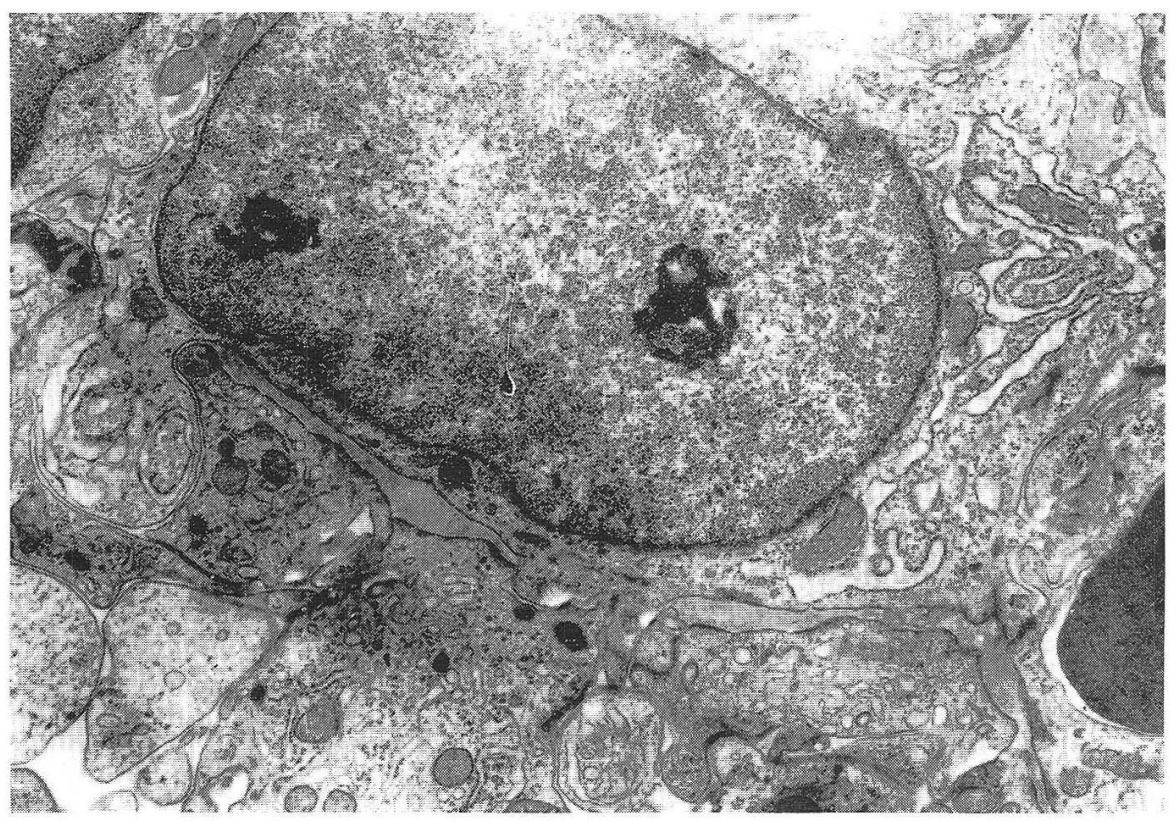

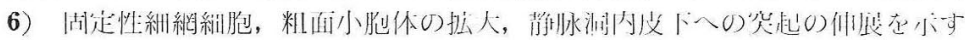




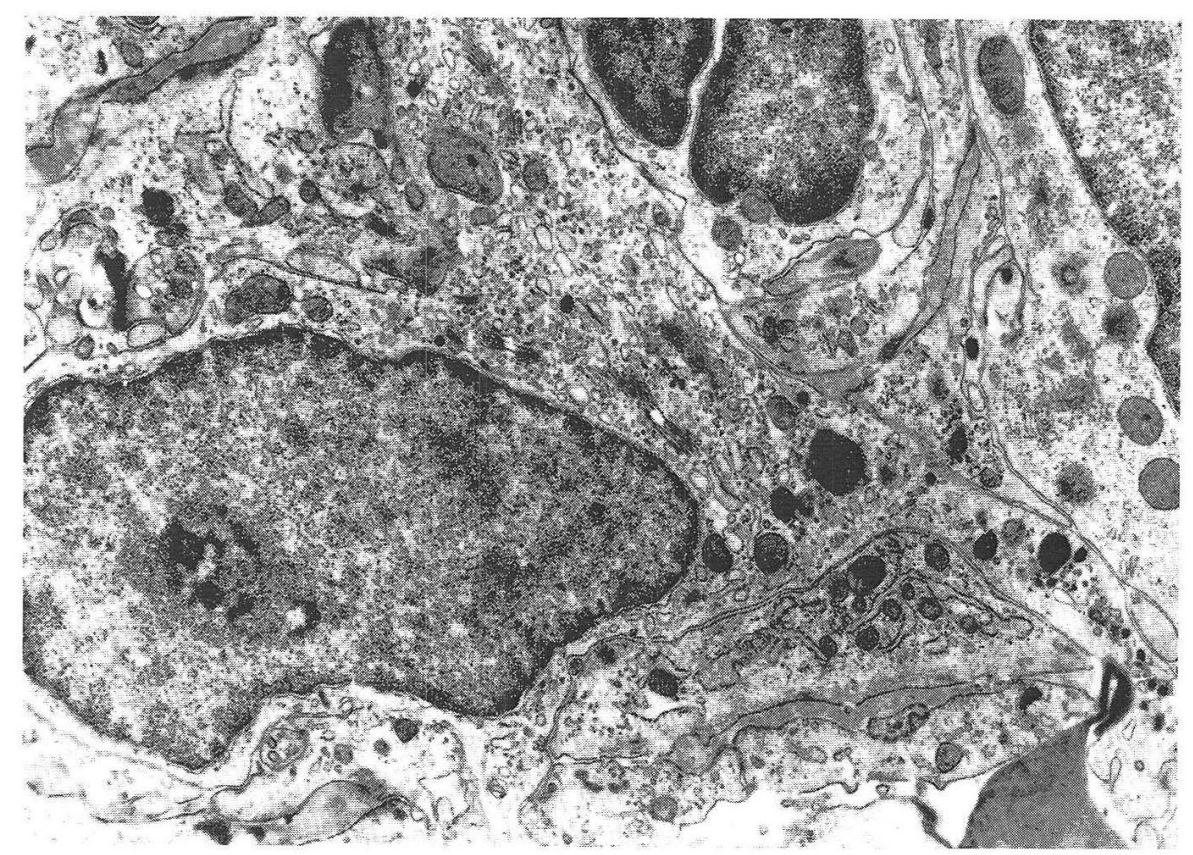

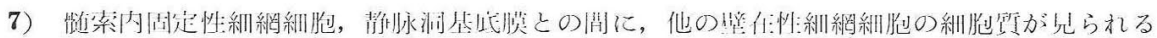

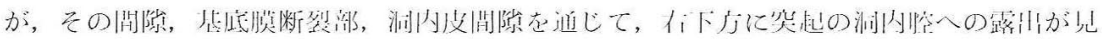

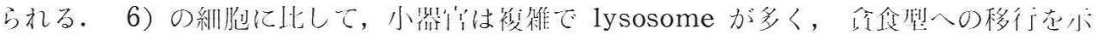
す. $\times 11,500$

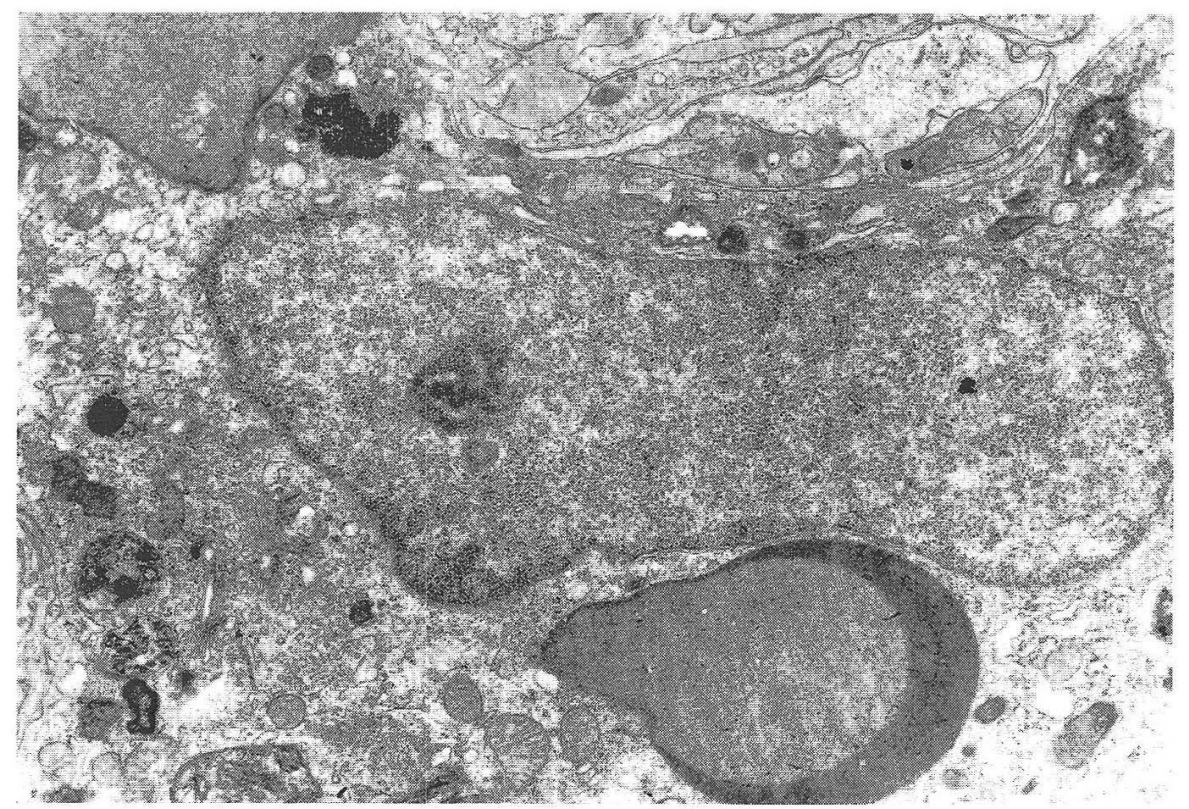

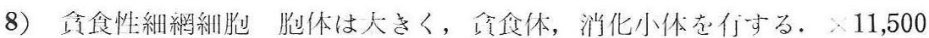




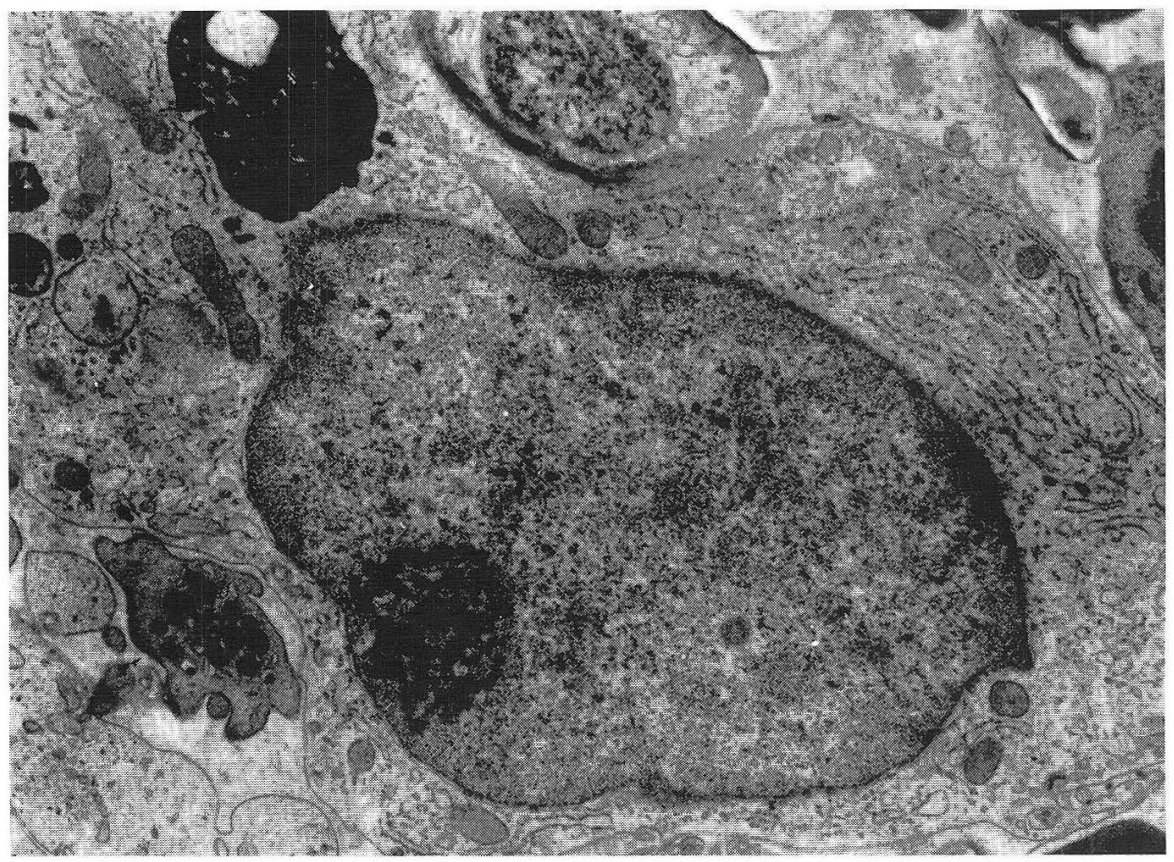

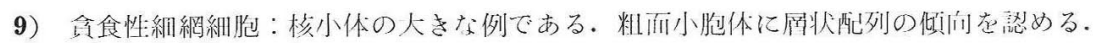
$\times 11,500$

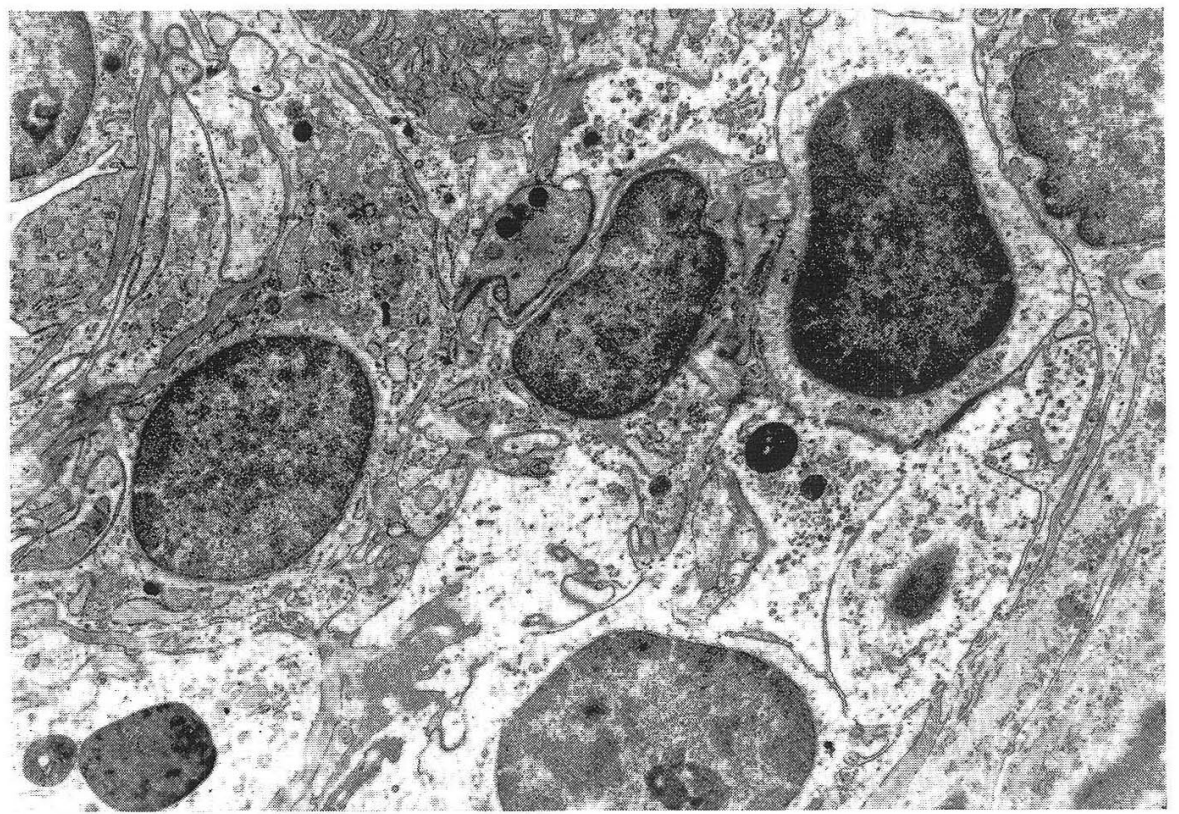

10）細動脉（苂動脉）周囲細絧細胞：左端に内文細胞が見え，すぐ外側に lysosome を有す る紡鍾形細胞が見られる。周囲のやや明るい紐胞質も，細絧細胞の突起の一部である. 